\title{
GEOCHEMICAL CHARACTERISTICS OF THE GEOTHERMAL FLUIDS IN THE AKROPOTAMOS AREA (MACEDONIA, NORTHERN GREECE)
}

\author{
Arvanitis A. ${ }^{1}$, Dotsika E. ${ }^{2}$ and Kolios N. ${ }^{3}$ \\ ${ }^{1}$ Institute of Geology and Mineral Exploration, $1^{\text {st }}$ Sp. Louis St., Olympic Village, 13677, \\ Acharnae, Greece, arvanitis@igme.gr \\ ${ }^{2}$ Institute of Nanoscience and Nanotechnology, National Center for Scientific Research \\ 'Demokritos', Patriarchou Grigoriou and Neapoleos St., 15310, Agia Paraskevi, Greece, \\ e.dotsika@inn.demokritos.gr \\ ${ }^{3}$ Geothermiki Hellas Ltd, 67200, Neo Erasmio, Xanthi, Greece, kolios@geothermikihellas.gr
}

\begin{abstract}
The geothermal field of Akropotamos produces fluids at temperatures up to $90^{\circ} \mathrm{C}$. The waters from wells AKR-1, AKR-3, AKR-4, AKR-5 and AKR-6 at 30-86 C and TDS of 3.1-30.7 g/l are classified as $\mathrm{Na}-\mathrm{Cl}$ type. The water from well $\mathrm{AKR}-2$ at $46^{\circ} \mathrm{C}$ with TDS of $2.15 \mathrm{~g} / \mathrm{l}$ belongs to $\mathrm{Na}-\mathrm{HCO}_{3} \mathrm{Cl}$ type. The cold and sub-thermal waters (16.4$27^{\circ} \mathrm{C}$ ) in the area are considered as fresh or low salinity waters (TDS: 0.31-4.34 g/l) of various mixed types. The $\mathrm{Na}-\mathrm{Cl}$ geothermal waters can be divided into two categories due to two different hot aquifers: (a) The first shallow aquifer contains high salinity waters (TDS: 27.4-30.7 g/l) at 30-48 C located within sands, sandstones and gravels. (b) The second deeper reservoir composed of calcareous conglomerates and sandstones contains lower salinity waters (TDS: 3.1-5.08 g/l) at 83-90 C. The contribution of seawater to the chemical composition of the thermal waters in the shallow aquifer system seems to be important. With the aid of chemical geothermomometers applied to the geothermal water from well AKR-1, the deep temperature has been estimated to be $>120^{\circ} \mathrm{C}$. Significant quantities of $\mathrm{CO}_{2}$ are encountered in wells AKR-1 and AKR-3.

Keywords: hydrochemistry, low enthalpy field, Kavala, Strymonikos Gulf.
\end{abstract}

\section{Пєрíi $\eta \psi \eta$}

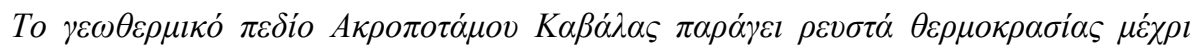

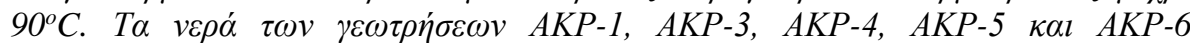

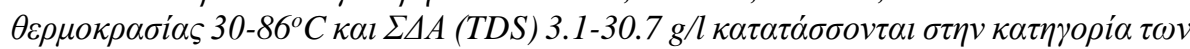

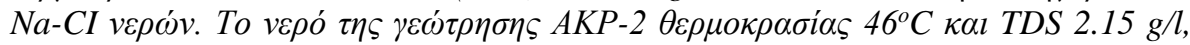

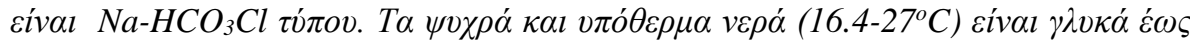

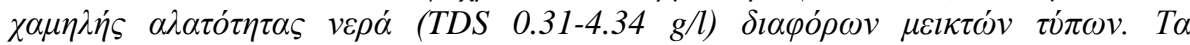

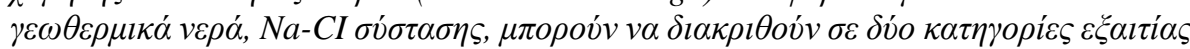

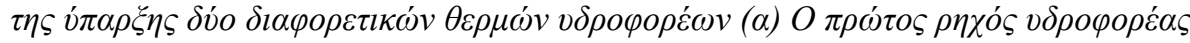

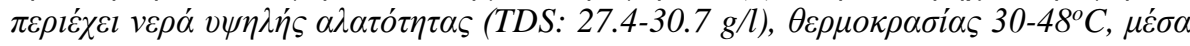

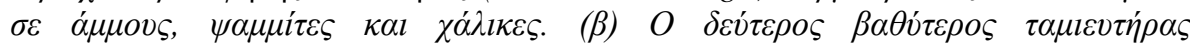

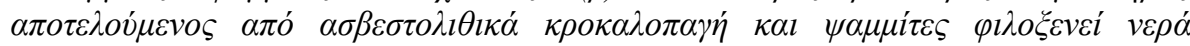

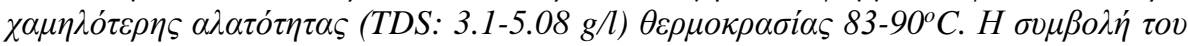




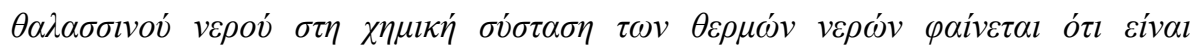

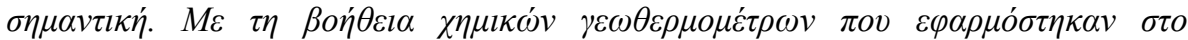

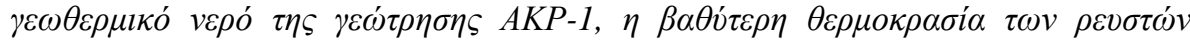

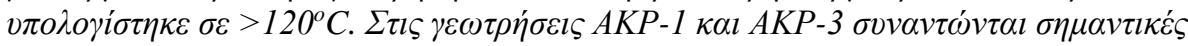
$\pi о \sigma o ́ \tau \eta \tau \varepsilon \varsigma \mathrm{CO}_{2}$.

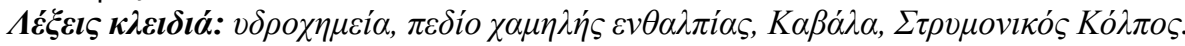

\section{Introduction}

The low enthalpy geothermal field of Akropotamos is located in the eastern coastal zone of the Strymonikos Gulf (or Orfanos Gulf) in Macedonia (Northern Greece). It was discovered after systematic geothermal investigation conducted by the Institute of Geology and Mineral Exploration (I.G.M.E.) during 2002-2006. This project was supported financially by the $3^{\text {rd }}$ Community Support Framework 2000-2006 (Operational Programme 'Competitiveness'). A detailed reconnaissance study including evaluation of geological and tectonic setting of the wider area, geoelectrical surveys, water temperature measurements at the heads of the existing irrigation and water supply wells, water chemistry analyses and evaluation of their results resulted in the construction of 6 large-diameter (production) wells at depths of $180-545 \mathrm{~m}$. Geothermal fluids of $38-90^{\circ} \mathrm{C}$ were found at $100-545 \mathrm{~m}$ depths. This paper presents the geochemical characteristics of the geothermal, sub-thermal and cold waters in the Akropotamos area.

\section{Geological and Tectonic Setting and Geothermal Conditions}

\subsection{Geological and Tectonic Setting}

The Akropotamos area belongs to the wider area of the Strymon basin, which has been formed between the Serbomacedonian Massif (west) and the Rhodope Massif (east), having been filled with Miocene formations (basal conglomerates and breccias, alternations of clays, sandstones, marls, lignite layers, limestones), Pliocene sediments (layers of clays, conglomerates, travertines, marls, red clays, sandstones, siltstones, limestones, lignites) and Pleistocene deposits (alternations of sands, clays, sandstones, marls, siltstones, conglomerates and limestones) (Lalechos, 1986; P.P.C., 1988) of a total thickness reaching about $4 \mathrm{~km}$. The Strymonikos Gulf can be considered as an offshore extension of the Strymon basin southeastwards separated from the continental basin by a horst (tectonic uplift) close to the present estuary of the Strymon River. Oil exploration borehole APOLLONIA (AP-1) of 3,146 m depth was drilled in the Strymonikos Gulf (Figure 1), penetrating Pleistocene-Holocene deposits (alternating sands, clays and sandstones with locally lignite intercalations), Pliocene-Miocene sediments (alternating sandstones, siltstones, clays and marls) and alternations of dolomites, sandstones, limestones and anhydrites near the base of the Miocene formations (Lalechos, 1986).

The Akropotamos area lies close to the tectonic contact ('Strymon line') between Serbomacedonian and Rhodope Massifs (Figure 1). The geological basement is made up of gneisses, amphibolites and schists belonging to the Kerdylia Series of the Serbomacedonian Massif (west) and marbles (dominant rock type) and gneisses belonging to the Pangeon Unit of the Rhodope Massif (east). Tertiary granitoids have intruded into the metamorphic rocks of the basement (Eleftheriadis et al., 2001). The oldest Miocene sediments of the Akropotamos area consist of basal conglomerates, sands, coarse-grained sandy marls and sandstones having a total thickness more than $500 \mathrm{~m}$. Eastwards, Miocene thick-bedded biogenic limestones having high secondary porosity are located. The sedimentary series has been developed uniformly towards the Pliocene. Pliocene sediments consist of travertine deposits, marine sands and clays and calcarenites. Southwards, the entire series is covered with recent coastal and fluvial-torrential deposits and scree (Kolios et al., 2010).

The Akropotamos area is dominated by NW-SE and NE-SW faults. The NW-SE faults have been activated as oblique sinistral normal faults with high dip angles. The NE-SW faults are common in 
the area, probably associated with the Kavala-Xanthi-Komotini fault zone and have been activated as oblique dextral normal faults. During Lower Quaternary, the wider area was affected by NW-SE and NE-SW striking faults. Two main tectonic blocks are observed: the Akropotamos horst and the Pieria graben (east of the geothermal area). The entire area has been influenced by the presence of the North Anatolia Fault Zone (Kolios et al., 2010).

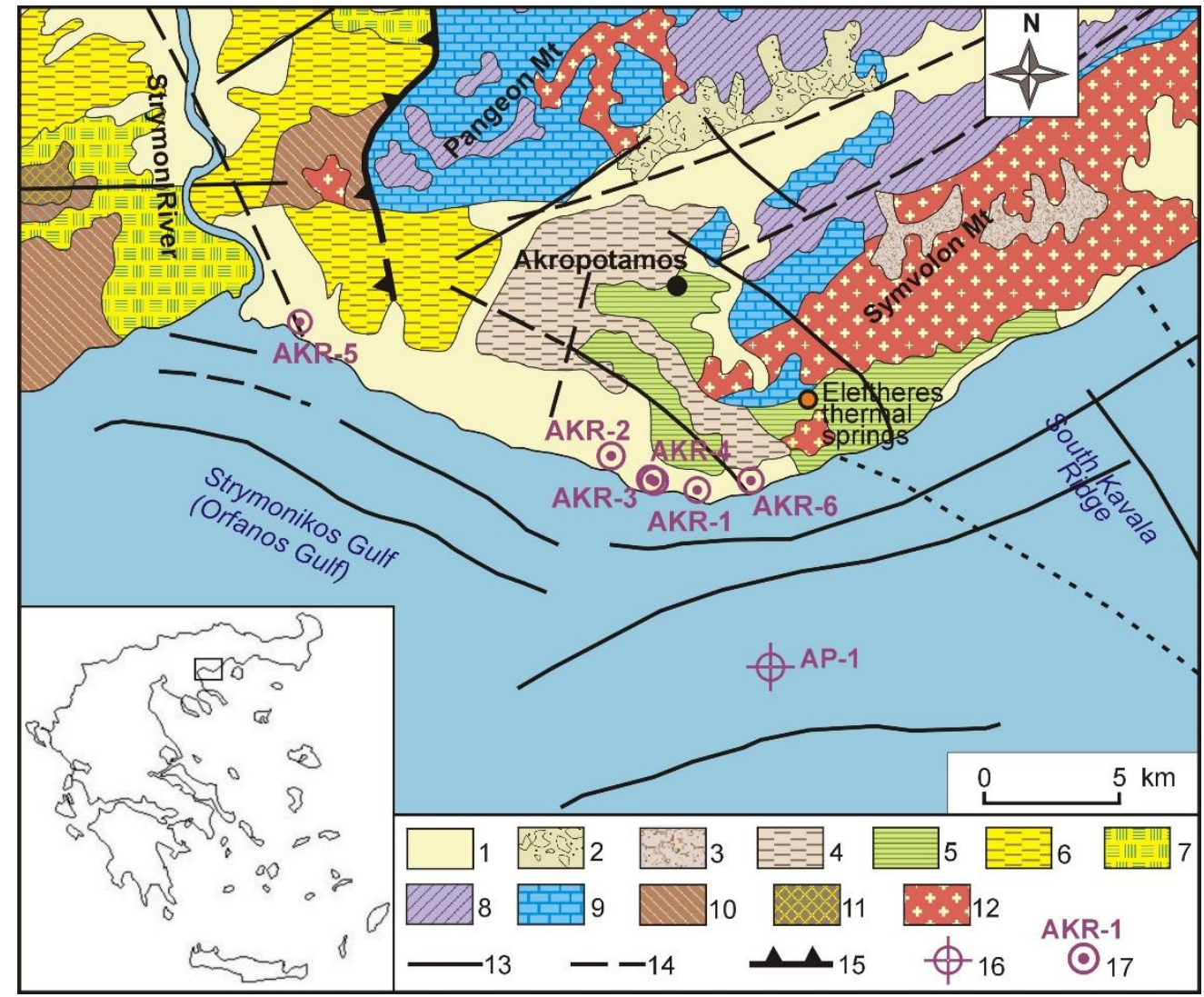

Figure 1 - Simplified geological map of the Akropotamos area with the sites of the geothermal wells and offshore oil exploration borehole AP-1 (Kolios et al., 2010).

[1: Alluvial deposits in valleys and coastal deposits, 2: Alluvial fans and older talus cones -

Scree, 3: Pleistocene lacustrine and continental deposits (clays, loams, sands, conglomerates,

4: Pleistocene marine deposits (marls, clays, sands, conglomerates, coastal terraces), 5:

Pliocene marine sediments (conglomerates, sands, clays, marls, marly limestones), 6: Mio-

Pliocene lacustrine and terrestrial sediments (conglomerates, sands, marls, clayey material, marly limestones and clays), 7: Mio-Pliocene marine sediments (the above-mentioned detrital sediments), 8: Amphibolites, gneisses, schists with marble intercalations (Rhodope Massif), 9: Marbles or crystalline limestones (Rhodope Massif), 10: Amphibolites, gneisses, schists with some marble intercalations (Serbomacedonian Massif), 11: Gneisses

(Serbomacedonian Massif), 12: Tertiary granitoids, 13: Fault, 14: Probable fault, 15:

Strymon tectonic line, 16: Oil exploration borehole, 17: Geothermal well].

The compilation of this map is based on the geological map of Greece at a scale of 1:500,000

(I.G.M.E., 1983) with some additional tectonic structures derived from the 1:500,000-scale seismotectonic map of Greece (I.G.M.E., 1989) and some modifications according to Lalechos (1983) and Pollak (1979). 


\subsection{Geothermal Conditions}

Being located about $3 \mathrm{~km}$ E-NE of the Akropotamos coastal area, the hot springs of Eleftheres (Figure 1) with water temperatures at $38.7-53^{\circ} \mathrm{C}$ constitute the only natural thermal manifestation in the wider area and their presence is related to a fault or intersecting faults. In the Akropotamos area, irrigation and water supply wells (30-240 $\mathrm{m}$ depth) produce waters at $16.2-31.3^{\circ} \mathrm{C}$.

The preliminary geothermal exploration resulted in the construction of 6 large diameter wells (AKR1, AKR-2, AKR-3, AKR-4, AKR-5 and AKR-6). The sites of these wells are shown on Figure 1. Well AKR-1 has a depth of $275 \mathrm{~m}$ and yields geothermal waters at $83^{\circ} \mathrm{C}$ with artesian flow of 150 $\mathrm{m}^{3} / \mathrm{h}$ and large amounts of dissolved $\mathrm{CO}_{2}$. Well AKR-2, $410 \mathrm{~m}$ deep, produces $25 \mathrm{~m}^{3} / \mathrm{h}$ of water at $46^{\circ} \mathrm{C}$. Well AKR-3 was drilled down to $515 \mathrm{~m}$ and yields about $200 \mathrm{~m}^{3} / \mathrm{h} \mathrm{CO}_{2}$-rich geothermal fluids at $90^{\circ} \mathrm{C}$ with artesian flow. Next to this borehole, well AKR-4 was drilled at $180 \mathrm{~m}$ penetrating a shallow aquifer with water temperatures up to $49.7^{\circ} \mathrm{C}$ and has a discharge of $40 \mathrm{~m}^{3} / \mathrm{h}$ of water at $48^{\circ} \mathrm{C}$. Well AKR-5, $422 \mathrm{~m}$ deep, was drilled close to the Strymon river's mouth and the temperature of $27.8^{\circ} \mathrm{C}$ was measured at $280 \mathrm{~m}$. The last well AKR-6 was drilled in the eastern part of the geothermal field reaching a depth of $545 \mathrm{~m}$ and the temperature of $38^{\circ} \mathrm{C}$ was recorded at $503 \mathrm{~m}$. The primary geothermal interest manifests itself in the area between production wells AKR-2 and AKR1 along the coastal terrain. Two hot aquifers have been identified in this area: (a) a shallow aquifer at $100-185 \mathrm{~m}$ depth containing high conductivity $(14,000-38,000 \mu \mathrm{S} / \mathrm{cm})$ waters at $46-49.7^{\circ} \mathrm{C}$ and (b) a deeper reservoir at depths of $240-515 \mathrm{~m}$ containing lower conductivity $(3,600-8,160 \mu \mathrm{S} / \mathrm{cm})$ fluids at temperatures up to $90^{\circ} \mathrm{C}$ (Kolios et al., 2010).

In offshore oil exploration borehole AP-1, the temperatures of $59-67$ and $121-130^{\circ} \mathrm{C}$ were recorded at depths of 1,335 and $3,146 \mathrm{~m}$ respectively and the average geothermal gradient is estimated to be $36.5^{\circ} \mathrm{C} / \mathrm{km}$.

\section{Materials and Methods}

Eighteen cold $\left(16.2-19.5^{\circ} \mathrm{C}\right)$ and eight sub-thermal $\left(20.2-26.5^{\circ} \mathrm{C}\right)$ water samples were collected from various irrigation and water supply wells in the wider area of Akropotamos during August 2002. Additionally, two hot $\left(31.3\right.$ and $\left.49^{\circ} \mathrm{C}\right)$ waters were sampled from wells in the same period. Geothermal water sampling was performed from production wells AKR-1, AKR-2, AKR-3, AKR4, AKR-5 and AKR-6 drilled by I.G.M.E. during 2003-2006. All these sampling sites are illustrated in Figure 2. The collected samples were analyzed and major ions $\left(\mathrm{Na}^{+}, \mathrm{K}^{+}, \mathrm{Ca}^{2+}, \mathrm{Mg}^{2+}, \mathrm{Cl}^{-}, \mathrm{HCO}_{3}{ }^{-}\right.$, $\left.\mathrm{SO}_{4}{ }^{2-}, \mathrm{NO}_{3}{ }^{-}\right)$, trace elements $\left(\mathrm{Li}^{+}, \mathrm{Sr}^{2+}, \mathrm{Mn}^{2+}, \mathrm{NH}_{4}{ }^{+}, \mathrm{F}^{-}, \mathrm{Br}^{-}, \mathrm{NO}_{2}^{-}, \mathrm{PO}_{4}{ }^{3-}, \mathrm{Fe}, \mathrm{B}, \mathrm{I}_{2}\right)$ and $\mathrm{SiO}_{2}$ were determined. Gas sampling was carried out from production well AKR-1 and the gases were analyzed by gas chromatography at the Laboratory of the Chemical Engineering Department at Aristotle University of Thessaloniki. For reasons of comparison, the chemical analysis results of a water sample from the Eleftheres hot springs have been taken into account.

\section{Results and Discussion}

\subsection{Water Chemistry}

The results of chemical analyses of water samples are plotted on the Piper (1944) trilinear diagram (Figure 3) and according to Davis and De Wiest (1966) classification, the waters in the Akropotamos area are distinguished into groups, as follows: (a) The geothermal waters from wells AKR-1, AKR3, AKR-4, AKR-5 and AKR-6, at temperatures of $30-86^{\circ} \mathrm{C}$ with TDS (Total Dissolved Solids) of 3.1-30.7 g/l, are classified as Na-Cl type. (b) The geothermal water from well AKR-2 at $46^{\circ} \mathrm{C}$ with TDS values of $2.15-2.20 \mathrm{~g} / \mathrm{l}$ is of the $\mathrm{Na}-\mathrm{HCO}_{3} \mathrm{Cl}$ type. The sample from the Eleftheres thermal springs $\left(\mathrm{t}=41^{\circ} \mathrm{C}, \mathrm{TDS}=2.37 \mathrm{~g} / \mathrm{l}, \mathrm{pH}=6.20\right)$ belongs to the same water type. (c) The waters emerging from wells $\mathrm{AK} 11$ and $\mathrm{AK} \Theta$ are hot $\left(31.3\right.$ and $\left.49^{\circ} \mathrm{C}\right)$ having lower TDS contents $(0.42$ and $1.34 \mathrm{~g} / \mathrm{l})$ than geothermal ones and classified as $\mathrm{Ca}, \mathrm{Mg}, \mathrm{Na}-\mathrm{HCO}_{3}$ and $\mathrm{Ca}, \mathrm{Mg}-\mathrm{HCO}_{3}$ types respectively. They show $\mathrm{pH}$ values of 7.73 and 6.86. (d) The sub-thermal waters (AK1, AK7, AK12, AK17, AK18, AK23, AK25, AK26) of $20.2-26.5^{\circ} \mathrm{C}$ have TDS in the range of $0.68-4.34 \mathrm{~g} / \mathrm{l}$, show $\mathrm{pH}$ values of 
7.31-8.88 and belong to the $\mathrm{Ca}, \mathrm{Mg}, \mathrm{Na}-\mathrm{HCO}_{3} \mathrm{Cl}, \mathrm{Ca}, \mathrm{Mg}, \mathrm{Na}-\mathrm{Cl}, \mathrm{Ca}, \mathrm{Mg}, \mathrm{Na}-\mathrm{HCO}_{3} \mathrm{SO}_{4} \mathrm{Cl}, \mathrm{Na}-$ $\mathrm{HCO}_{3}\left(\mathrm{SO}_{4}\right), \mathrm{Ca}, \mathrm{Mg}, \mathrm{Na}-\mathrm{SO}_{4} \mathrm{HCO}_{3}, \mathrm{Na}-\mathrm{HCO}_{3} \mathrm{SO}_{4}$ and $\mathrm{Na}-\mathrm{HCO}_{3} \mathrm{Cl}$ types. (e) The cold waters (16.2$19.5^{\circ} \mathrm{C}$ ) with TDS of 0.31-4.27 $\mathrm{g} / 1$ and $\mathrm{pH}$ of 7.51-8.36, are classified into different types ('mixed waters') depending on the concentrations of main cations and anions and their contributions to the total cationic and anionic charges respectively.

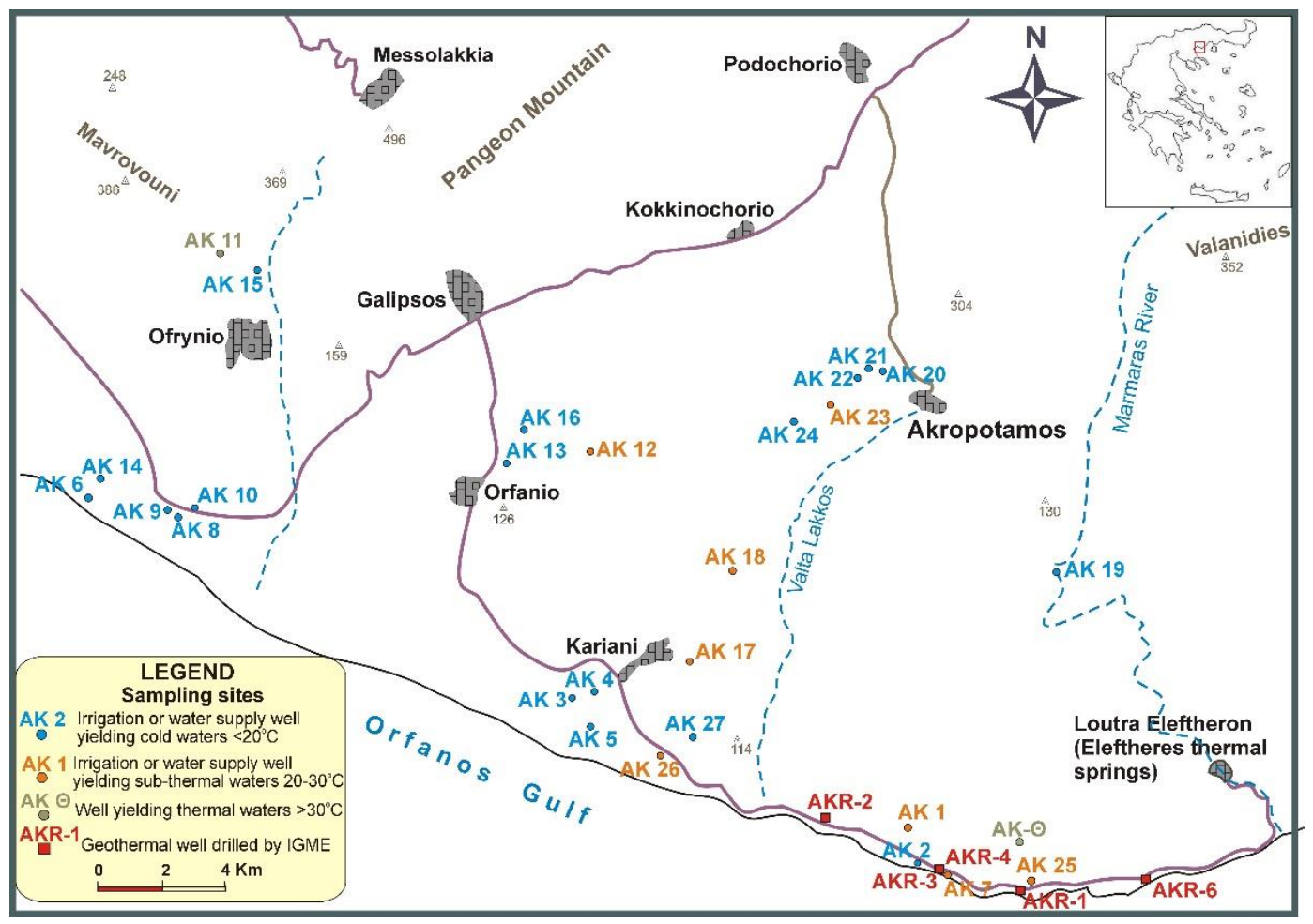

Figure 2 - Map showing the water sampling sites in the Akropotamos area.

The geothermal waters from the production wells drilled by I.G.M.E. along the coastal terrain are classified as $\mathrm{Na}-\mathrm{Cl}$ and $\mathrm{Na}-\mathrm{HCO}_{3} \mathrm{Cl}$ types. The water from well $\mathrm{AKR}-2\left(\mathrm{t}=46^{\circ} \mathrm{C}, \mathrm{TDS}=2.15 \mathrm{~g} / \mathrm{l}\right.$, $\mathrm{pH}=7.28$ ) comes from a hot aquifer at depth greater than $282 \mathrm{~m}$ consisting of sandstones and belongs to the $\mathrm{Na}-\mathrm{HCO}_{3} \mathrm{Cl}$ type. The other geothermal waters are of the $\mathrm{Na}-\mathrm{Cl}$ type and they can be divided into two groups: (a) The first group includes the waters from wells AKR-1 and AKR-3 which have TDS values of 5.08 and $3.1 \mathrm{~g} / \mathrm{l}$ respectively. These geothermal waters come from reservoirs located at depths of 240-275 $\mathrm{m}$ (calcareous conglomerates) and 480-515 m (sandstones) and they have temperatures at 83 and $90^{\circ} \mathrm{C}$ respectively. In these waters, the corresponding $\mathrm{Na}^{+}$concentrations have been determined to be 1,700 and $1,060 \mathrm{mg} / \mathrm{l}$ and the $\mathrm{Cl}^{-}$concentrations are 2,198.5 and 1,248.2 $\mathrm{mg} / \mathrm{l}$. (b) The second group includes the waters from wells AKR-4, AKR-5 and AKR-6 at temperatures of $30-48^{\circ} \mathrm{C}$. These waters are characterized by high values of electrical conductivity $(37,360-47,120$ $\mu \mathrm{S} / \mathrm{cm})$ and TDS (27.44-30.72 $\mathrm{g} / \mathrm{l})$ with $\mathrm{pH}$ of 6.13-7.55. They are mainly rich is $\mathrm{Na}^{+}(8,500-9,600$ $\mathrm{mg} / \mathrm{l})$ and $\mathrm{Cl}^{-}(14,539-17,659 \mathrm{mg} / \mathrm{l})$. Their $\mathrm{Ca}^{2+}, \mathrm{Mg}^{2+}, \mathrm{K}^{+}$and $\mathrm{SO}_{4}{ }^{2-}$ concentrations have been determined to be $344-882$, 946-1232, $150-300$ and up to $2,590 \mathrm{mg} / \mathrm{l}$ respectively. These high ion concentrations can be attributed to the intense influence of seawater on their chemical composition. Data from wells AKR-3 and AKR-4 drilled down to different depths at a short distance (only a few meters) from each other provide useful information about the seawater influence. Well AKR-3, $515 \mathrm{~m}$ deep, yields fluids at $90^{\circ} \mathrm{C}$ from the deeper reservoir (sandstones) and well AKR-4, $180 \mathrm{~m}$ deep, extracts waters at $48^{\circ} \mathrm{C}$ from a shallow (114-180 m) hot aquifer (pebbles and consolidated sandstones). The chemical composition of geothermal waters produced from these production wells is differentiated because they come from different reservoirs. Additionally, water conductivity logs performed in wells 
AKR-2, AKR-3, AKR-4 and AKR-5 have recorded a rapid and high increase at depths of 100-220 m and the values decrease at greater depths. The maximum value of 34,000 $\mu \mathrm{S} / \mathrm{cm}$ was measured at 165 $m$ depth in well AKR-4 (Kolios et al., 2010). Taking account the chemical composition of the seawater in Northern Greece (Dominco and Papastamataki, 1975; Minissale et al., 1989) the influence of seawater on the waters of the shallow geothermal aquifer is highly probable.

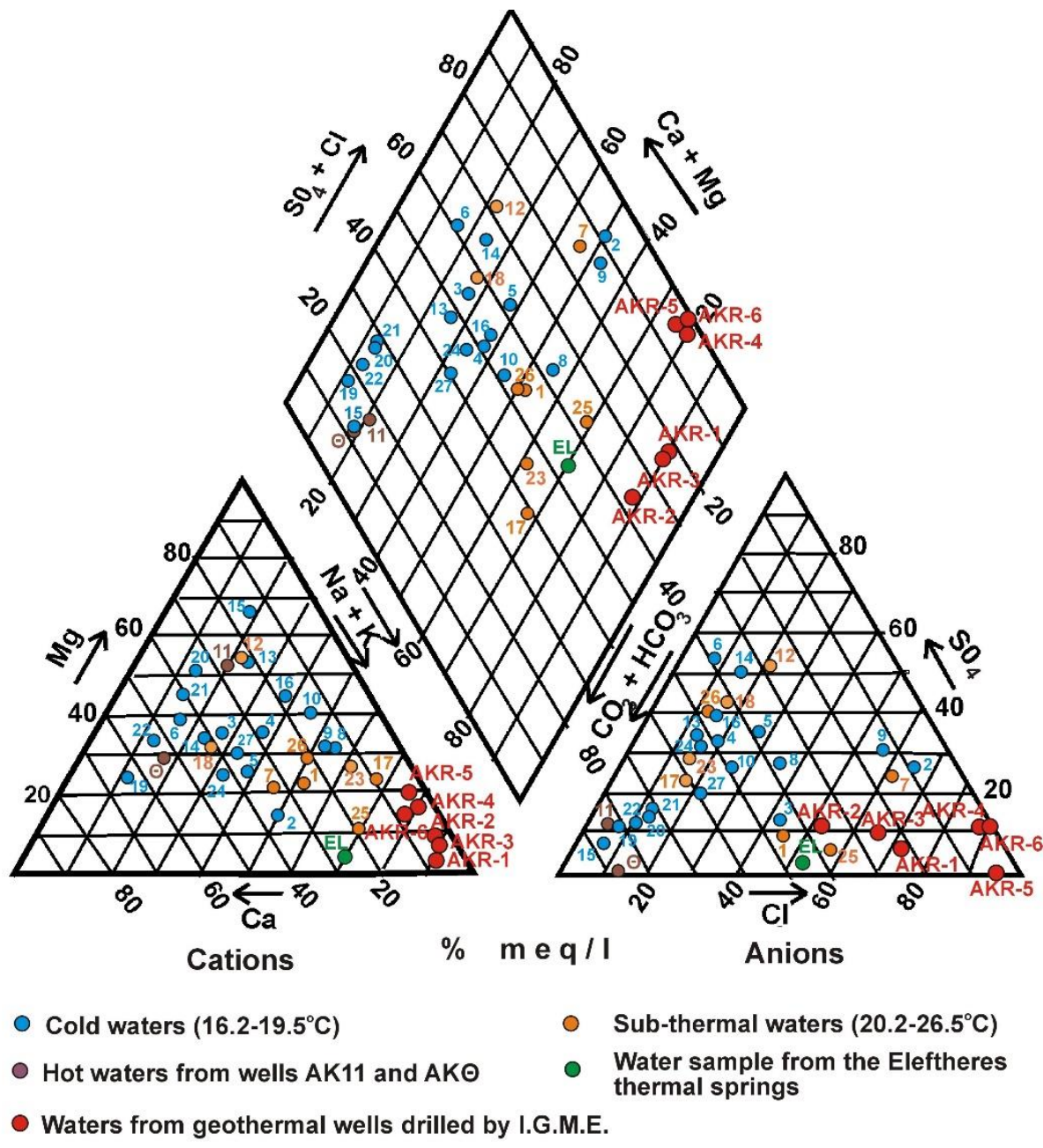

Figure 3 - Plotting the results of chemical analyses of cold, sub-thermal and geothermal waters from the Akropotamos area on the Piper (1944) trilinear diagram.

Along the coastal terrain between the mouth of Strymon River and the Eleftheres thermal springs (Figures 1 and 2), the cold and sub-thermal waters from irrigation and water supply wells are classified into various water types depending on the percentages of anions and cations in the total anionic and cationic charges respectively. Some of these water samples show increased concentrations of $\mathrm{Na}^{+}, \mathrm{K}^{+}, \mathrm{Ca}^{2+}, \mathrm{Mg}^{2+}, \mathrm{Cl}^{-}$and $\mathrm{SO}_{4}{ }^{2-}$ as a result of probable influence of seawater on shallow aquifers. The differentiation in their chemical composition can be explained by the different mixing percentages between sea water and meteoric waters. Thus, waters coming from irrigation and water supply wells located at a considerable distance from the coast have lower $\mathrm{Na}^{+}$and $\mathrm{Cl}^{-}$ concentrations than the other ones mentioned above.

Correlation diagrams between TDS and the contents of $\mathrm{Na}^{+}, \mathrm{Ca}^{2+}, \mathrm{Cl}^{-}, \mathrm{SO}_{4}{ }^{2-}, \mathrm{Mg}^{2+}$ and $\mathrm{K}^{+}$for collected waters from geothermal and other irrigation and water supply wells along the coastal terrain show that 
the concentrations of $\mathrm{Na}^{+}, \mathrm{Cl}^{-}$and $\mathrm{Mg}^{2+}$ contribute significantly to the TDS levels. Additionally, correlation diagrams between the water temperature and the concentrations of various chemical species indicate that there is no obvious linear relationship between them and only the $\mathrm{SiO}_{2}$ contents vs. temperature diagram shows that that the temperature tends to increase the solubility of this chemical compound indicating the probable geothermal origin of the dissolved silica. In general, the chemical characteristics of the waters depend on the lithology and mineral composition of the geological formations through which the fluids have passed easily and/or where they have been stored (aquifers, reservoirs). The seawater appears to influence the chemical composition of waters. Samples from geothermal wells AKR-1, AKR-2 and AKR-3 show a Na/Cl ratio of 1.19-1.31. These values are slightly higher than that of seawater $(\mathrm{Na} / \mathrm{Cl}=0.876)$. In contrast, geothermal waters AKR-4, AKR-5 and AKR-6 have a $\mathrm{Na} / \mathrm{Cl}$ ratio of 0.79-0.90. $\mathrm{Na}^{+}$vs. $\mathrm{Cl}^{-}$correlation diagram shows that samples AKR-4, AKR-5 and AKR-6 are plotted near the seawater mixing-line and especially close to the seawater point.

\subsection{Determination of scaling and corrosion tendencies of geothermal waters}

The scaling and corrosion tendencies of geothermal waters in the Akropotamos area have been estimated. Two indices have been used to evaluate the tendency of these waters for $\mathrm{CaCO}_{3}$ scaling: the Langelier Saturation Index (LSI or Langelier Index) and the Ryznar Stability Index (RSI). The LSI values have been calculated to be $+0.33,-0.04$ and +0.20 for samples AKR-2, AKR- 4 and AKR6 respectively, indicating that these waters are in equilibrium with $\mathrm{CaCO}_{3}$, not tending to dissolve or precipitate it. For geothermal waters AKR-1, AKR-3 and AKR-5, this index takes values of +1.28 , +1.81 and +1.65 respectively, showing that these waters have a significant tendency to deposit $\mathrm{CaCO}_{3}$. The values of the Ryznar Index range between 4.25 and 6.95. Specifically, values of 4.254.53 (less than 7) have been calculated for samples AKR-1, AKR-3 and AKR-5 suggesting a strong tendency to form $\mathrm{CaCO}_{3}$ scale. On the contrary, the RSI values range from 6.21 to 6.95 for samples AKR-2, AKR-4 and AKR-6 determining their little scale forming (or slight corrosion) tendencies and therefore these waters are considered to lie within a stability zone (equilibrium or neutral zone).

Regarding the corrosivity of geothermal waters in the Akropotamos area, the following points can be noted: (a) The Total Key Species (TKS) vary between 1,694.7 and 19,274.4 mg/l. (b) The $\mathrm{Cl}$ fraction in TKS ranges from 40.2\% to 91.6\% (for waters AKR-4, AKR-5 and AKR, the TKS are in the range of 17,457.2-19,274.4 ppm with $\mathrm{Cl}$ fraction $>80 \%$ ). The chloride ion favours the corrosion. (c)The $\mathrm{pH}$ values range from 6.13 to 8.15 . The lower the $\mathrm{pH}$, the greater the corrosive tendency of the water. Samples AKR-1, AKR-2, AKR-4, AKR-5 and AK-6 have $\mathrm{pH}<7.6$. (d) The temperatures of geothermal waters range between 30 and $90^{\circ} \mathrm{C}$.

\subsection{Gas Chemistry}

Significant quantities of gases are encountered in geothermal wells AKR-1 and AKR-3. A high dissolved $\mathrm{CO}_{2}$ content characterizes these waters, which favours the leaching of the surrounding rocks. Gas sample from well AKR-1 was taken and analyzed by gas chromatography. The dominant gas is $\mathrm{CO}_{2}(>99.5 \% \mathrm{v} / \mathrm{v})$. The content of other gases (mainly $\left.\mathrm{CH}_{4}\right)$ does not exceed $0.01 \% \mathrm{v} / \mathrm{v}$.

\subsection{Geothermometry}

With the aid of chemical geothermometers of $\mathrm{SiO}_{2}$ (Fournier, 1981), Na/K (Arnorrson et al., 1983), Na-K-Ca (Fournier and Truesdell, 1973), Na-Li (Fouillac and Michard, 1981), K-Mg (Giggenbach et al., 1983) and Li-Mg (Kharaka and Mariner, 1989) the deeper reservoir temperatures have been calculated (Table 1).

$\mathrm{The} \mathrm{SiO}_{2}$ geothermometer (Fournier, 1981) provides values between 65.8 and $121.5^{\circ} \mathrm{C}$ (the value of $27.7^{\circ} \mathrm{C}$ for sample AKR-6 is not acceptable). The temperature of $121.5^{\circ} \mathrm{C}$ is considered to be reliable. The $\mathrm{Na} / \mathrm{K}$ geothermometer (Arnorrson et al., 1983) suggests temperatures ranging from 63.5 to $176.0^{\circ} \mathrm{C}$ and higher computed temperatures of $127.3-195.4^{\circ} \mathrm{C}$ are derived by the use of the $\mathrm{Na}-\mathrm{K}-\mathrm{Ca}$ geothermometer (Fournier and Truesdell, 1973). The Na-Li (Fouillac and Michard, 1981) and LiMg (Kharaka and Mariner, 1989) empirical chemical geothermometers were applied to the sample 
from the Eleftheres thermal springs giving values of 110.8 and $91.0^{\circ} \mathrm{C}$ respectively. $\mathrm{The}^{\mathrm{L}}{ }^{+}$ concentrations were not determined in the water samples collected from the geothermal wells of the area and therefore, the Na-Li and $\mathrm{Li}-\mathrm{Mg}$ geothermometers can not be applied to them.

Table 1 - Calculation of the deep reservoir temperatures by the use of various chemical geothermometers.

\begin{tabular}{|c|c|c|c|l|c|c|c|}
\hline $\begin{array}{c}\text { Water } \\
\text { Sample }\end{array}$ & $\begin{array}{c}\mathbf{T}\left({ }^{\circ} \mathbf{C}\right) \text { at } \\
\text { well-head }\end{array}$ & $\begin{array}{c}\mathbf{T}\left({ }^{\circ} \mathbf{C}\right) \\
\mathbf{S i O}_{2}\end{array}$ & $\begin{array}{c}\mathbf{T}\left({ }^{\circ} \mathbf{C}\right) \\
\mathbf{N a} / \mathbf{K}\end{array}$ & $\begin{array}{c}\mathbf{T}\left({ }^{\circ} \mathbf{C}\right) \\
\mathbf{N a}-\mathbf{K}-\mathbf{C a}\end{array}$ & $\begin{array}{c}\mathbf{T}\left({ }^{\mathbf{}} \mathbf{C}\right) \\
\mathbf{N a} / \mathbf{L i}\end{array}$ & $\begin{array}{c}\mathbf{T}\left({ }^{\circ} \mathbf{C}\right) \\
\mathbf{K}-\mathbf{M g}\end{array}$ & $\begin{array}{c}\mathbf{T}\left({ }^{\circ} \mathbf{C}\right) \\
\mathbf{L i}-\mathbf{M g}\end{array}$ \\
\hline AKR-1 & 83.0 & 121.5 & 176.0 & $\begin{array}{l}195.4 \\
(\beta=1 / 3)\end{array}$ & --- & 134.9 & --- \\
\hline AKR-2 & 46.0 & 82.5 & 77.1 & $\begin{array}{l}127.3 \\
(\beta=1 / 3)\end{array}$ & --- & 63.4 & --- \\
\hline AKR-3 & 90.0 & --- & 165.7 & $\begin{array}{l}195.0 \\
(\beta=1 / 3)\end{array}$ & --- & 99.1 & --- \\
\hline AKR-4 & 48.0 & 93.5 & 108.4 & $\begin{array}{l}169.4 \\
(\beta=1 / 3)\end{array}$ & --- & 95.2 & --- \\
\hline AKR-5 & 30.0 & 65.8 & 63.5 & $\begin{array}{l}132.9 \\
(\beta=1 / 3)\end{array}$ & --- & 74.4 & --- \\
\hline AKR-6 & 38.0 & 27.7 & 91.3 & $\begin{array}{l}150.5 \\
(\beta=1 / 3)\end{array}$ & --- & 91.4 & --- \\
\hline EL & 41.0 & 97.8 & 175.9 & $\begin{array}{l}173.0 \\
(\beta=1 / 3)\end{array}$ & 110.8 & 101.3 & 91.0 \\
\hline
\end{tabular}

Waters from geothermal wells (AKR-1, AKR-2, AKR-3, AKR-4, AKR-5, AKR-6) and the Eleftheres thermal springs (EL) plotted on the Giggenbach (1988) trilinear diagram show the following results (Figure 4): (a) Samples AKR-2, AKR-3 and EL are plotted in the area of 'immature waters'. Immature waters show that there is no water-rock equilibrium and therefore the use of the $\mathrm{Na} / \mathrm{K}$ geothermometer is unsuitable and the estimations of the deep reservoir temperatures using cation geothermometers should be interpreted with caution. For not too acid waters, the K-Mg geothermometer may be used and its application to the above-mentioned geothermal waters gives temperatures of $63.4-134.9^{\circ} \mathrm{C}$. (b) Samples AKR-1, AKR-4, AKR-5 and AKR-6 are plotted in the 'partial equilibrium' field (Figure 4) and their positions on this diagram indicate probable deeper reservoir temperatures in the ranges of $80-130^{\circ} \mathrm{C}$ (at shallower levels, $\mathrm{t}_{\mathrm{km}}$ ) and $120-215^{\circ} \mathrm{C}$ (at considerable depth, $\mathrm{t}_{\mathrm{kn}}$ ).

Considering the temperatures calculated by various chemical geothermometers, the predicted deep reservoir temperatures range from 100 to $150^{\circ} \mathrm{C}$ or probably even higher. The increased $\mathrm{SiO}_{2}$ content of geothermal water AKR-1 indicates its deeper geothermal origin (the solubility of $\mathrm{SiO}_{2}$ increases with increasing temperature up to $340^{\circ} \mathrm{C}$ ), probably reflects the reservoir conditions and therefore the calculated value of $121.5^{\circ} \mathrm{C}$ (Table 1 ) seems to be very probable and realistic. In addition, temperature measurements in offshore deep oil exploration boreholes in the wider area have given the following values: (a) $121-130^{\circ} \mathrm{C}$ at a depth of $3,146 \mathrm{~m}$ in borehole $\mathrm{AP}-1$, (b) $144.4^{\circ} \mathrm{C}$ at $3,225 \mathrm{~m}$ depth in borehole S. KAVALA-2 and (c) $153.9^{\circ} \mathrm{C}$ at a depth of 3,441 $\mathrm{m}$ in borehole PERAMOS-1 (Chiotis, 1988). These values fall within the range of temperatures estimated by $\mathrm{SiO}_{2}$ and $\mathrm{K}-\mathrm{Mg}$ geothermometers and Giggenbach's ternary diagram (1988).

Finally, based on the composition of gas phase and using the D'Amore and Panichi's (1980) geothermometer for sample EL, the deep reservoir temperature was calculated at $93^{\circ} \mathrm{C}$ (Minissale et al., 1989). 


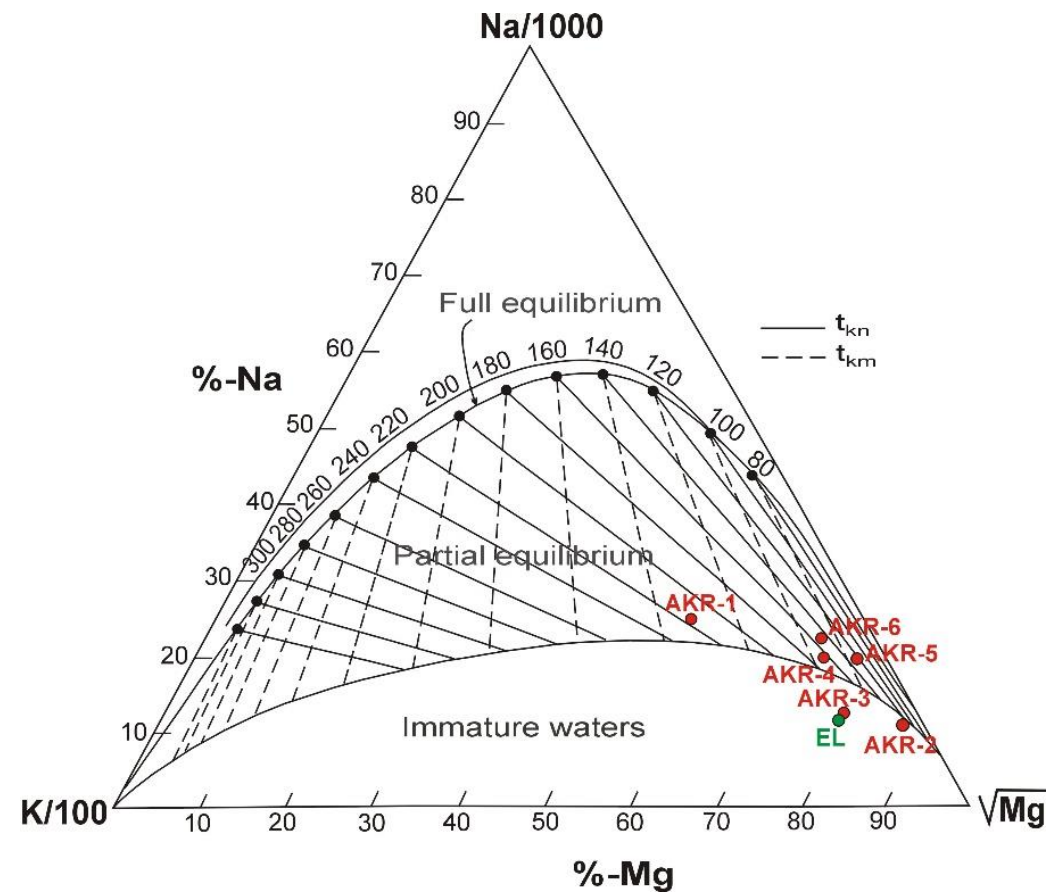

Figure 4 - Plotting the water samples AKR-1, AKR-2, AKR-3, AKR-4, AKR-5, AKR-6 and EL on the Giggenbach (1988) trilinear diagram.

\subsection{Isotope Geochemistry}

The isotope ratios may reflect various physicochemical processes in geothermal systems such as water-rock interaction, mixing or steam separation. In particular, isotopes of oxygen and hydrogen are suitable markers for tracing water defining mechanisms that affect fluids.

The isotope composition, ${ }^{2} \mathrm{H}$ and ${ }^{18} \mathrm{O}$, is indicated in delta notation, versus VSMOW standard as: $\delta=\left(\left(\mathrm{R}_{\text {sample }}-\mathrm{R}_{\text {standard }}\right) / \mathrm{R}_{\text {standard }}\right) * 1000$, where $\mathrm{R}_{\text {sample }}$ and $\mathrm{R}_{\text {standard }}={ }^{2} \mathrm{H} /{ }^{1} \mathrm{H}$ or ${ }^{18} \mathrm{O} /{ }^{16} \mathrm{O}$ ratios of sample and standard respectively. Determination of the different isotope ratios has the following precisions: $\pm 1 \%$ for $\delta^{2} \mathrm{H}$ and $\pm 0.2 \%$ for $\delta^{18} \mathrm{O}$.

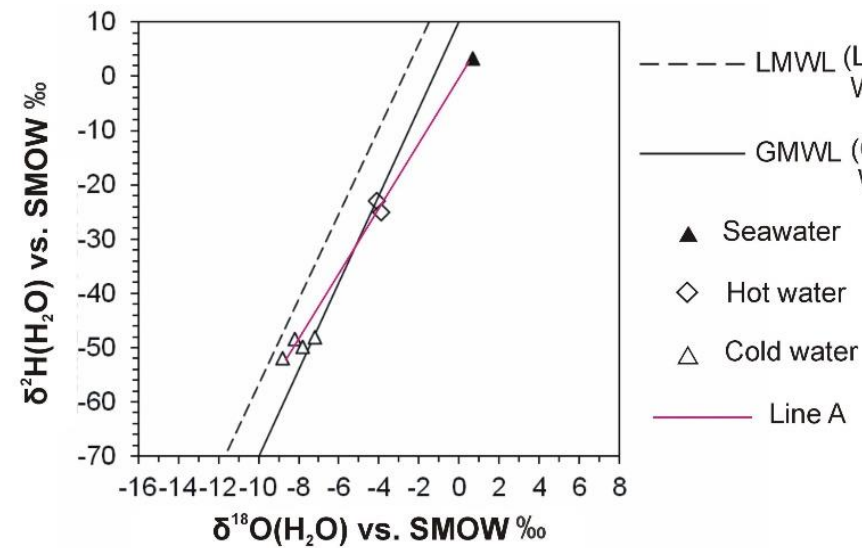

Figure 5 - Graph of $\delta^{2} \mathrm{H}\left(\mathrm{H}_{2} \mathrm{O}\right)$ vs. SMOW \%o - $\delta^{18} \mathrm{O}\left(\mathrm{H}_{2} \mathrm{O}\right)$ vs. SMOW \%o for cold and geothermal waters in the Akropotamos area. 
The isotopic composition for cold and geothermal waters ranges from $-8.8 \%$ o to $-3.9 \%$ for $\delta^{18} \mathrm{O}$ and from $-51.9 \%$ o to $-23.2 \%$ for $\delta^{2} \mathrm{H}$. Hot waters from the Akropotamos area are shown in Figure 5. In the same figure, the seawater is also reported. Line A is an ideal mixing line between seawater and fresh water. Some of the samples have been plotted into the mixing area confirming the ratios of sea water participation as calculated by $\mathrm{Cl}-\mathrm{Na}$.

\section{References}

Arnorrson, S., Gunnlaugsson, E. and Svavarsson, H. 1983. The chemistry of geothermal waters in Iceland III, Chemical geothermometry in geothermal investigations, Geochim. Cosmochim. Acta, 47, 567-577.

Chiotis, E., 1988. Evaluation of temperature measurements in oil wells in Greece, Bull. Geol. Soc. Greece, XX/3, 197-215.

D'Amore, F. and Panichi, C., 1980. Evaluation of deep temperatures of hydrothermal systems by a new gas geothermometer, Geochim. Cosmochim. Acta, 44, 549-556.

Davis, S.N. and De Wiest, 1966. Hydrogeology, New York, John Wiley \& Sons, 463 pp.

Dominco, E. and Papastamataki, A., 1975. Characteristics of Greek geothermal waters, Proc. $2^{\text {nd }}$ U.N. Symp. Dev. Use Geoth. Resources, S. Francisco, 109-121.

Eleftheriadis, G., Frank, W. and Petrakakis, K., 2001. ${ }^{40} \mathrm{Ar} /{ }^{39} \mathrm{Ar}$ Dating and Cooling History of the Pangeon Granitoids, Rhodope Massif (Eastern Macedonia, Greece), Bull. Geol. Soc. Greece, XXXIV/3, Athens, 911-916.

Fouillac, C. and Michard, G., 1981. Sodium lithium ratio in water applied to geothermometry of geothermal reservoirs, Geothermics, 10, 55-70.

Fournier, R.O. and Truesdell, A.H., 1973. An empirical Na-K-Ca geothermometer for natural waters, Geochimica et Cosmochimica Acta, 37, 1255-1275.

Fournier, R.O., 1981. Application of water geochemistry to geothermal exploration and reservoir engineering. In: Rybach, L. and Muffler, L.J.P., eds., Geothermal Systems: Principles and Case Histories, 109-143, New York, Wiley.

Gavrielides, G., 1990. Study of the subsurface aquifer conditions of the Eleftheres curative spring, Proc. of the $2^{\text {nd }}$ Congress on the thermal mineral waters (Thessaloniki, Greece, 1988), Hellenic Association of Municipalities and Communities of Curative Springs and Spas, Thessaloniki, 155-166.

Giggenbach, W.F., Gonfiantini, R., Jangli, B.L. and Truesdell, A.H., 1983. Isotopic and chemical composition of Parbati Valley geothermal recharges, NW Himalaya, India, Geothermics, 12,199-222.

Giggenbach, W.F., 1988. Geothermal solute equilibria. Derivation of Na-K-Mg-Ca geoindicators, Geochim. Cosmochimica Acta, 52, 2749-2765.

Institute of Geology and Mineral Exploration (I.G.M.E.), 1989. Seismotectonic map of Greece with seismological data, Scale 1:500000, Athens.

Kharaka, Y.K. and Mariner, R.H., 1989. Chemical geothermometers and their application to formation waters from sedimentary basin. In: Naeser, N.D. and Mc Collon, T.H., eds., Thermal History of Sedimentary Basins, 99-117, N. York, Springer-Verlag.

Kolios, N., Arvanitis, A., Karydakis, G. and Koutsinos, S., 2010. Geothermal drilling activity in the Akropotamos area, Bull. Geol. Soc. Greece, XLIII/5, 2246-2256.

Lalechos, N., 1986. Correlations and Observations in Molassic Sediments in Onshore and Offshore Areas of Northern Greece, Mineral Wealth, 42, 7-34.

Minissale, A., Duchi, V., Kolios, N. and Totaro, G., 1989. Geochemical characteristics of Greek thermal springs, Journal of Volcanology and Geothermal Research, 39, 1-16.

P.P.C. (Public Petroleum Corporation), 1988. Inventory of low enthalpy geothermal resources disc overed through deep oil and gas exploration wells, Athens, 42-53.

Piper, A.M., 1944. A graphic procedure in the geochemical interpretation of water analysis, Tran s. Amer. Geophysical Union, 25, 914-928.

Pollak, W.H., 1979. Structural and lithological development of the Prinos - Kavala basin, Sea of Thrace, Greece, Annales Géologique des Pays Helléniques, Tome bors serie, 2, 1003-1011. 